ISSN No. 0974-035X

An Indexed, Refereed \& Peer Reviewed Journal of Higher Education

Towards Excellence

UGC-HUMAN RESOURCE DEVELOPMENT CENTRE,

GUJARAT UNIVERSITY, AHMEDABAD, INDIA

\title{
RECOGNIZING THE IMPORTANCE AND STRUGGLES OF WOMEN: AN ECOFEMINIST READING OF ANITA DESAI'S NOVELS: FIRE ON THE MOUNTAIN AND WHERE SHALL WE GO THIS SUMMER?
}

\author{
Ms. Anjali Daud Parmar \\ Prof. Ami Upadhyay
}

\section{Abstract}

This research article glances in a few words at the concept of ecofeminism and the interconnectedness of woman and nature and their struggle. Earth belongs to all creatures on this planet so human has to share equally with them. All living things on earth have equal share on each and everything on this planet between them, But for the game called survival, human is destroying other things for their own benefits only. Since humanity is inseparable from nature, it is necessary to live in harmony to save the human race as well as the world from the damage and destructions which that demands the need of co existence. It is not only a movement but philosophies. Anita Desai is deeply fascinated by ecofeminism perception and through her novels she is trying to lead her readers to believe that nature and woman are resolving tools to the universal problems arising in today's scenario. Through the close reading of Desai's novel, I have explored the concept of ecofeminism. The present paper tries to reveal the features of ecofeminism through the portrayal of characters- Nanda Kaul and Sita in the Fire on The Mountain and Where shall We go This Summer? Respectively.

Ecofeminism as an ideology and movement finds that the oppression of women is interlinked to the oppression of nature with the same masculine centred attitudes and practices concerning to the patriarchal society. Ecofeminism has its roots in literature also.Google defines ecofeminism as "a philosophical and political theory and movement which combines ecological concerns with feminist ones, regarding both as resulting from male domination of society." (http://en.wikipedia.org/wiki/ecofeminism) 
Ecofeminism has been described as a third wave of feminism, a branch of deep ecology, an environmental critique of feminism, and a feminist critique of environmentalism. In mid sixties and the early seventies, all over India, there were students and some activist protested and started morchas and tribal movements. And women participated in large number in these movements against the women's operation and violence and gender discrimination. The women who came out with movements in recent time are MedhaPatkar, Mahasweta Devi, Arundhati Roy and C.K. Janu and many more. In India, it is surprising that male writers such as Amitav Gosh(The Hungery Tide), Indrasinha (Animal's people) and the only Female writer Arundhati Roy to be included in the field of postcolonial Indian ecofeminism.

This paper examines the elements of ecofminism in Anita Desai's novels- Fire On the Mountain and Where shall we go in This Summer?. Desai presented nature as an integral part of her works in the form of creation, destruction and preservation. Anita Desai, a significant figure in Indian literature, also portrays the tragedy of human souls trapped in the awkward situations of life. Through her writing, she has given a new dimension to the success of Indian Women novelists in English writings. She presents the tension and turmoil of women. As far as Anita Desai is concerned, she writes mostly about the miserable conditions of women suffering under the male dominance society, who is an object of gaze in the masochistic society where she is playing different roles as, a daughter, a wife, a mother, an artist or a writer. Most of her characters are distressed and alienated from the world, from the society, from the families, from parents, and even from their own selves. The most of her novels are situate among the cultural and social changes.

Anita Desai is indisputably one of the most leading contemporary Indian authors in English. She has been known as a literary genius equally in India and abroad. She was born on June 24, 1937 in Missouri, a hill station near Dehradun in northern India. She grew up surrounded by Western literature and music. Her father D.N. Mazumdar was a Bengali and Toni Nime her mother was a German and both met in Germany, then she immigrated to Indian 1920s. According to Wier, Ann Lowry:

"Anita Desai is the vanguard of a new generation of Indian writers who are experimenting with themes of inner consciousness. She gives her reader a valuable insight into the feminine consciousness through her memorable protagonists." (Weir Anna, Lowry. "The Illusions of Maya: Perspective on Anita Desai”. Journal of South Asian Literature, 1891, p.21) 
Anita Desai belongs to the group of women writers who have offered their experience to literature. She is recognized today for her originality and versatility as well as the indigenous favours she has on offer in the portrayal of the characters in her fictions.

She was determined to be a writer and continued to compose and publish short stories and mainly fiction. Desai has contributed to various prominent literary publications and in the New York Times Book Review, London Magazine, Harper's Bazaar and Quest. As a novelist

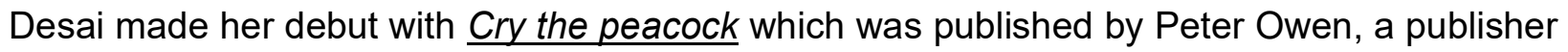
mainly interested in literature of the British Commonwealth and continental Europe in Britain. At that time no publisher would be paying attention on Indian authors and their writings but because of England's natural interest in India, Desai's work came to be noticed first in England. Moreover in India the psychological novel was first introduced in the tradition of Virginia Woolf by none other than Anita Desai. She admits that D H Lawrence, Virginia Woolf, Henry James and Proust had influenced her more strongly in her twenties when she had first begun to work on her first novel, Cry the Peacock, has been considered as the starting point of psychological fiction in Indian writing in English. The story deals with the psychological consciousness of Maya, the female protagonist, it means illusion in Hindi. The readers are confronted with the hopelessness of her situation: her despair, anxiety, dread, anguish and her choice in the given situation, which leads her to insanity.

Desai's second novel Voices in the City, offers a moving picture of the life of another female character like Maya, named Monisha. Desai has portrayed feminine psyche through Monisha in the novel. Motherhood is the ultimate object of the female and that is why the significance of and craving for children, play a very important role in Desai's novels. She continues this theme in her second novel with Monisha, but in Where Shall We Go This Summer? And Fire on The Mountain, she portrayed women with children. The novel Bye Bye Blackbird, treats the problems of adjustment of Indian Immigrants in England. From 1973 to 1982, she gave three novels, Where Shall We Go This Summer? , Fire on The Mountain and Clear light of Day which discuss the issues like conformity and rebellion, attachment and detachment. She writes about caste because she knows them very well and can understand them. The Village by the Sea is the only novel which ends in total harmony. Moreover it is considered to be a part of children's fiction.

In the third phase of her career Desai has written two novels, In Custody and Baumgartner's Bombay which presents some deviation from Anita Desai's earlier novels as the major protagonists, Deven, and Hugo represent male psyche. Then after she has produced three 
Parmar \& Prof. Ami Upadhyay/ Page 289-297

novels in her mature phase: Journey to Ithaca, Fasting, Feasting and Zigzag Way, at what time her daughter Kiran Desai has also started writing novels.

Anita Desai portrays her women characters by giving them a deep sense of humanness despite their apparent potentialities and weaknesses. Her novels have been observed as manifestoes of female predicament and creative, feminine sensibility. Her novels also explore the myth of man's unquestionable superiority and the myth of woman being martyr and a paragon of all virtues. She closely examines the emotional world of woman kind, focussing on how her heroines bravely struggle against or helplessly submit to the relentless forces of absurd life in contemporary urban milieu. More over they are not completely cut off from familial and social ties instead of remaining within these orbits, they protest against monotony, injustice and humiliation. Her heroines are not mere robots but individuals. She has presented them both extremes: sensitive women and the thick-skinned ones with dull sensibility and minutely examines their world of emotions.

From the very beginning of the human civilization, Nature -Physical environment has been appeared as a primary source of living and income. As a free gift of nature, natural resources have been used and misused the way human being likes to use it, as a result natural resources are being degraded and gradually fading away the natural setting with the concern of the universal threats revolving around us. By the close reading of the novels of Anita Desai like where shall we go this Summer? and especially, in Fire on the mountain, we find the connection between the nature and woman, and the importance of nature. Even the title itself points out the Nature symbolism. Desai's fully involvement with the atmosphere, background and to the details of Indian scene is the leading element in the novel like trees, season, birds, mountains, gardens symbolize the grim reality of existence, originality, hope, freshness etc

Fire on the Mountain is generally considered to be Anita Desai's masterpiece. The title is derived from the noble prize winner William Golding's celebrated novel entitled, 'Lord of the Flies' second chapter 'fire on the Mountain'.

Nature lovers will fall prey to the very first chapter of the book, as the author describes the Kausauli, the place where Nanda Kaul, the Protagonist is spending her best years of her life; the author depicts her character with everything around nature, how she influenced her surroundings and each at of hers defining her mental status so that we can read her mind. Anita Desai's Fire on the Mountain is set in Carignano in Kasauali, at the backdrop of the Shimla hills and wonderfully portrays the Indian life. The novel deals with the three women characters - the worst sufferers being the women character -Nanda, Raka and Ila's the 
personal struggle of and their oppressed life,. Throughout the novel, these characters have fire burning inside; confront to overcome the societal limitations imposed on them by the Patriarchal culture. The road of self discovery is found through the characters of the novel. The novel is written in three parts which are interconnected: Nanda Kaul at Carignano, Raka comes to Carignano and lla Das leaves Carignano respectively which is divided into several unequal short chapters, like acts of a drama followed by epilogue in which the writer examines the significant action occurring within the psyches of Nanda Kaul and her great granddaughter Raka as well as her friend lla Das.

The novel deals with the marginal, unimportant, loneliness, isolation and agony in the life of the protagonist, Nanda Kaul. Nanda Kaul, a great grandmother, has renounced her entire world; living in isolation has come to Kausauli to spend her remaining days in the peace of mountain. It was her love for nature which brought her to the desolate place Carignano: the place of isolation and bareness as her past life was full of suffering and miseries. Here Anita Desai narrates that Nanda kaul is a symbol of Mountain or Forest which Raka has set it on fire. Desai has explored the perfect example of Greek tragedy in this novel by presenting the three noble characters. Nanda Kaul her aloofness and disillusionment, Ila Das with her flexibility and anti social and screeching voice and Raka with her independence transgress the expectations of femininity that is care giver and dependence. And they have to sacrifice and suffer not only because of their personal flaw or lack but because of social limitations, and failure to recognize the worth of woman.

Through these three women character- Nanda Kaul, Raka and lla das , Anita Desai helps us to determine the invisible and darker side of the individual self which presents the real position and fate of a woman in India and trauma of a married woman who suffers from injustice and social in equality that takes refuge such as - A widow like Nanda Kaul who is economically independent, inflexible, incapable to accommodate anyone else in her small world of Craignano, the other lla Das, flexible, and ready to make all amendments and adjustments in life but fail to maintain dignity in the society or a girl Raka though a child psychologically stronger than her great grandmother, chooses to live recluse life as her life has been miserable by the disharmony of her parents who become innocent victims. But like fire they find the resolution and light in darkness. Desai's characters always attempts to triumph over the societal limitations imposed on them by the patriarchal culture. As a result, these three women lead to miserable life. Externally everything looks smooth but within, the fire which burns in the heart of Nanad Kaul with frustration, disappointment and suppressed emotions, she suffers in the voice of silence like Maya and Monisha. Whereas Ila emerges as 
a independent individual and fights against local priests. She thinks, the women are willing poor dears and meaningless existence, to try and transform their terrible lives by an effort. Thereby Nanda and Ila become representatives of the all women who must sacrificed for others.

Her fourth novel Where shall we go this Summer? describes the story of a middle aged woman with four children and pregnant for the fifth time -named Sita( a Protagonist) and her fatigue for life as she feels alienated in her own house. By seeing the destruction and meaningless existence around all over the world, she decides to abort her baby. And to prevent the birth of her baby, she withdraws to her childhood place in search of peace and pleasure-island of Manori.

Like Nanda Kaul, Sita also frustrated and fed up with the routine life of Mumbai as she fails to adjust with the city life as well as with the family and relatives too. She and her husband are poles apart. She is over sensitive and unable to understand the realities of life as life is not only the bundle of happiness, it is also a part of sufferings, struggles and pain too. Whereas her husband Raman is practical who fails to enlighten his wife towards the harsh realities of life. She is a representation of nature and cannot adjust or feels as a stranger in the mechanic world of Mumbai. Like Nanda Kaul Sita too wants to escape from Bombay and decides to live in Island of Manori by expecting a miracle could happen there.

"Fed up with the dreary metropolitan life in Bombay and tormented by the 'paranoiac' fear of her fifth and reluctant pregnancy she leaves for Manori islet off the Moris mainland." (Swain 21-22)

Due to the bitter childhood experiences and as a motherless child, Sita feels neglected, partiality and indifference from her childhood, are responsible for her insensible and abnormal behaviour towards the life.

On the contrary, when Sita and her children come at the Manori for vacation, her children are unable to adjust with the life of island as they live in the city comfortably. And they want to escape from the island to city. And later her Husband Raman takes them back. So at the end, sita too decides to follow her husband's footprint as her charm and miracle of island is vanished. She realises the harsh reality of life. "Life in Bombay is the reality; the island represents a stage world, an act of imagination of make belief, a world which collapses on close contact."(Jasbir 87) 
Sita is strained to believe the reality and she is baffled. "How could she tell, how decide? Which half of her life was real and which unreal? which of her selves was true, which false? All she knew was that there were two periods of her life, each in direct opposition to the other."(153)

As Hariom Prasad observes:

"Sita has come to accept the prosaic nature of life which runs through difficult human situations in different ways. She finds the courage to face life, in the end, with all its ups and downs."(119) The story ends when Sita is rescued once again from the island by her husband. Sita has deep feelings towards nature and discovers comfort in the midst of nature. She enjoys life in the company of nature just like her childhood experiences and feels nature is the best healer. It has the power to solve all our problems and rectify it with all its bounds

Here I have noticed that both Nanda and Sita discover the peace in the lap of nature and try to sooth their stressful life by freeing themselves from the so called duties and responsibilities. As Nanda is unhappy at the arrival of her great granddaughter Raka, she wants the secluded life at the Kasauli with company of nature. Sita too wants to aloof from all duties as a mother at the Manori and has refused to give birth to her child in this world. Hence Nature gives shelter to Nanda and Sita and also cures their physical and psychological problems and enables them to live peaceful life. Thus nature and woman are inseparable. They are the creators as well as preservers. Today it's our responsibility to save and protect the both to survive from the hazardous, we are facing.

To sum up, C. G. Shyamala ponders about Anita Desai that, "Desai has the power to express sensibilities in her canvas using images from nature...she is an artist who has the ability to carve such deep emotions within dexterous use of imagery that announce the introduction of the explorations of the selves within the ecological framework." (pp.7) 


\section{References:}

Desai, Anita. Where shall we go this summer? New Delhi: Orient Paperbacks, 1982.

Desai Anita, Fire On the Mountain. Random House India, Noida, 2008.

Bande Usha. The novels of Anita Desai: A study in Character and Conflict. New Delhi: Prestige books, 1988.

Bhatnakar M.K, editor. Indian Writing in English. V-I Atlantic Publishers and Distributors: New Delhi, 2001.

Belliappa, Meena. Anita Desai: A Study of her Fiction, Calcutta: writers workshop, 1971. 5060

Brown,C.S. The Reader's Companion to World Literature. Penguin New York, 1984.

Choudary, Bidulata. Woman and society in the novels of Anita Desai. Creative Book, New Delhi, 1995.

Jain, Jasbir. Stairs to the Attic: The novels of Anita Desai. Jaipur: Printwell Publishers, 1987.

Pathak, R. S. "The Alienated Self in the novels of Anita Desai", Indian Women Novelists, set. I, vol.II, ed. R.K. Dhawan. New Delhi: Prestige Books, 1991.

Prasad, Hariom. "Anita Desai's Where shall we go this summer?, As a critique of Existentialism", Studies in Indian Writing in English, ed. Rajeshwar Mittapalli. New Delhi: Atlantic Publishers and Distributors, 2004. 112-119

Rao, Ramachandra B. The Novels of Anita Desai. Ludhiana: Kalyani, 1977. 59- 62.

Srivastava, Ramesh K. Six Indian Novelists in English, Amristar: Guru Nanak Dev University, 1987. (221-230) The Indian Review of World Literature in English, Vol. 5 No. I January, 2009 13

Swain, S.P. "The Dialectics of Marital Polarisation in Anita Desai's Cry, the peacock", Studies in Indian Writing in English. ed. Rajeshwar Mittapalli. New Delhi: Atlantic Publishers and Distributors, 2000. 95-111

Tripathy, J.P. The Mind and the Art of Anita Desai. Bareilly: Prakash Book Depot, 1986. 


\author{
Anjali Daud Parmar \\ Asst. Prof., Ph.D. Scholar \\ Gujarat Technological University, Ahmedabad \\ \& \\ Prof. Ami Upadhyay \\ Director, School of Humanities \& Social Sciences \\ Dr.Babasaheb Ambedkar Open University,Ahmedabad.
}

